\title{
PERMANÊNCIAS E MUTAÇÕES NA DEFINIÇÃO INTERGERACIONAL DO TRABALHO INFANTIL*
}

\author{
Adriana Carnielli De Lima* \\ Ana Maria F. Almeida ${ }^{* * *}$
}

\begin{abstract}
RESUMO: O artigo discute a percepção de famílias dos grupos populares sobre o significado do trabalho infantil, apontando o enquadramento moral, cercado de ambiguidades, das decisóes tomadas pela geração mais velha de adiar a entrada dos filhos em ocupaçōes remuneradas. Embora suas decisões possam ser explicadas, pelo menos em parte, pela profundidade das transformações nas mentalidades que acompanharam a gênese da percepção da criança como um ser humano em formação e fundamentaram a transformação do trabalho infantil em prática ilegal e socialmente ilegítima, nosso estudo, não obstante, ajuda a mostrar que as ambiguidades percebidas podem ser explicadas pela história social das gerações em foco, que é, em grande parte, a história das transformações por que passou o Brasil nas últimas décadas, tanto no que diz respeito à sua estrutura produtiva, quanto à sua organização legal e espacial.
\end{abstract}

Palavras-chave: Educação e desigualdade. Socialização. Gerações. Trabalho infantil.

As autoras agradecem o financiamento do CNPq e da FAPESP, fundamental para a realização da pesquisa.

** Mestranda em Educação (UNICAMP) e professora da rede pública municipal de Campinas. E-mail: adrianacarnielli@gmail.com

*** Doutora em Educação e professora da Faculdade de Educação da Unicamp. E-mail: aalmeida@unicamp.br

Educ. Soc., Campinas, v. 31, n. 111, p. 347-369, abr.-jun. 2010

Disponível em <http://www.cedes.unicamp.br> 


\title{
CONTINUITIES AND MUTATIONS IN THE INTERGENERATIONAL DEFINITION OF CHILD LABOR
}

\begin{abstract}
This paper discusses how low-income families perceive the meaning of child labor. It points out the ambiguous moral vision that supports the decision made by the older generation to postpone the entrance of their children in the labor market. Such decisions can be explained, at least partly, by the deep transformations in mentalities that have followed the genesis of the perception of children as "human beings in formation" and founded the transformation of child labor into an illegal and socially illegitimate practice. Nevertheless, our study shows that the ambiguities noted may also be explained by the social history of the generations focused, which is, mainly, the history of the transformations that have taken place, these last decades, in the productive structures and in the legal and spatial organization of Brazil.
\end{abstract}

Key words: Education and inequality. Socialization. Generations. Child labor.

$P$

ara os estudos sobre a produção da desigualdade econômica, pensar em termos de geraçôes implica indagar sobre os processos dinâmicos de transmissão de recursos materiais e/ou simbólicos que podem ser mobilizados na luta para garantir, aos mais jovens, acesso a uma proporção considerada correta ou justa da riqueza coletivamente produzida em uma dada sociedade. Nas sociedades capitalistas contemporâneas, focalizar a dimensão educativa desses processos implica problematizar permanências e mutações das percepções e comportamentos que orientam os investimentos das famílias com relação ao futuro dos filhos, particularmente aquelas que se articulam com as decisões relativas ao trabalho e à ocupação, que permitem compreender, por exemplo, a opção ou não pela escola e a respectiva decisão de adiar ou antecipar a entrada no mercado de trabalho. ${ }^{1}$

Esse artigo pretende contribuir para essa discussão, apresentando resultados de uma pesquisa que examinou o sentido atribuído, por crianças e adultos de famílias de baixa renda, a uma série de atividades que as crianças desenvolviam, regularmente ou esporadicamente. Particularmente, a pesquisa procurou explorar o conteúdo das atividades definidas como "trabalho" e o lugar simbólico atribuído a elas e à escola no processo de criação dos filhos. 
As transformações no valor social das crianças

A abordagem canônica da questão tem sido convincente em relacionar as transformaçōes dos investimentos das famílias no futuro dos filhos e a progressiva preponderância da escola sobre o trabalho remunerado às profundas mudanças nas mentalidades que têm acompanhado a gênese da percepção da criança como "um ser humano em formação", transformando tudo aquilo que se associa a trabalho em prática socialmente ilegítima, quando exercido por crianças. ${ }^{2}$ Zelizer (1985, p. 7), por exemplo, estendendo para os Estados Unidos as hipóteses trabalhadas por Ariès (1981) em seus estudos sobre a "descoberta da infância" na Europa dos séculos XVI e XVII, documenta as transformações que fundamentaram, naquele país, a "emergência da criança 'sem valor', em termos econômicos, embora 'inestimável', em termos sentimentais".

A autora mostra que, já em meados do século XIX, os pais dos grupos médios urbanos já haviam deixado de atribuir valor econômico a suas crianças. Ao invés de contarem com os filhos para sua aposentadoria, por exemplo, os pais providenciavam arranjos financeiros para seu próprio sustento e investiam em educação para proteger os filhos economicamente improdutivos.

Nesse mesmo período, ao contrário, crescia o valor econômico das crianças trabalhadoras em consequência da industrialização. Aumentava, portanto, a dependência das famílias dos grupos trabalhadores com relação ao trabalho remunerado de suas crianças mais velhas, assim como ao trabalho doméstico dos mais jovens.

Entre 1870 e 1930, essas diferenças desapareceram. Os grupos populares viram suas práticas de criação dos filhos se tornarem "fora da lei”, por força da legislação que impôs a escolarização obrigatória e proibiu o trabalho infantil.

Enquanto os grupos médios tiveram condições de aderir mais precocemente a esta concepção de criança e, consequentemente, de promover as transformações de conduta de forma mais lenta, os grupos trabalhadores viram-se confrontados a essas novas regulações num espaço muito curto de tempo. Progressivamente, a "nova criança sagrada passou a ocupar um mundo separado e especial, regulado por afeição e educação, e não por trabalho e lucro" (Zelizer, op. cit., p. 209). 
A contribuição mais significativa do trabalho de Zelizer não se esgota no mapeamento dessas transformações, já que a autora demonstra convincentemente o "efeito independente dos fatores culturais na redefinição do valor das crianças nos Estados Unidos" (idem, ibid., p. 11).

Esse processo também teve lugar no Brasil e se materializou igualmente em torno das lutas contra o trabalho infantil, que mobilizam grupos de vários tipos, em diferentes frentes, inclusive produzindo um grande número de estudos que circulam por periódicos especializados. Esses trabalhos costumam apoiar-se em pesquisas que têm como objetivo reunir evidências dos prejuízos causados pelo trabalho sobre o desenvolvimento das crianças. Tratam-se aqui de estudos realizados por médicos, enfermeiros, pedagogos, psicólogos e juristas, mas também sociólogos e outros cientistas sociais, unidos em torno de um objetivo: apoiar ou propor iniciativas que exijam o afastamento das crianças do mercado de trabalho e seu direcionamento para a escola. Aprende-se, nesses textos, que o trabalho prejudica psicologicamente e fisicamente o desenvolvimento da criança e conclui-se que uma sociedade democrática não aceita impor o sacrifício do trabalho às suas crianças (Ferreira \& Valenzuela, 1998; Ferreira, 1999; Hoezel, 2000; Martins, 1993; Pires, 1988; Silva, 2000b).

Ora, como bem mostra Vera Marques (2003), essa missão a que se dedicam cientistas e juristas é simetricamente oposta àquela em que se envolveram os higienistas do início do século Xx, quando se engajaram numa luta de grandes proporções para transformar crianças pobres em cidadãos laboriosos, preconizando justamente o trabalho como terapia. Naquele momento, o trabalho era visto como "antídoto aos perigos decorrentes do ócio e do vício que 'rondavam' crianças pobres desocupadas" (Marques, op. cit., p. 58). Um século depois, a infância está, outra vez, no centro de uma cruzada salvacionista, porém no sentido contrário.

Essa radical transformação das visões sobre criança e trabalho no Brasil é resultado, claro, dos processos que contribuíram para fazer o trabalho infantil ser percebido como "problema social" (Lenoir, 1998). Ela só pode ser compreendida se articularmos, como propóe Marcos Ferreira (2001), os processos de consolidação democrática que impulsionaram a institucionalização das ações de proteção à infância, largamente entendidas como ações contra a exploração do trabalho infantil, 
com elementos do cenário internacional concretizados, em grande parte, pela mobilização da Organização Internacional do Trabalho (OIT) ao longo do século XX.

Isso tem orientado uma profícua agenda política que provocou importantes alterações na regulamentação da relação das crianças e adolescentes com o mercado de trabalho e continua gerando um volume significativo de políticas públicas, principalmente nas duas últimas décadas. Não é surpresa, portanto, que, segundo os dados oficiais, cerca de três milhôes de crianças e adolescentes com idade entre 5 e 17 anos tenham deixado o mercado de trabalho nos anos de 1990; uma redução que chegou a $51,6 \%$ no total dos trabalhadores na faixa etária de 5 a 9 anos (Brasil, 2004).

Como essa redução aconteceu em meio a uma conjuntura econômica e social adversa, esses números sustentam o argumento de que processos políticos devem ser levados em consideração para explicá-los. Nesse sentido, os números revelam a existência de uma luta simbólica pela imposição da ilegitimidade do trabalho infantil ao conjunto da sociedade brasileira.

Não obstante, o trabalho de crianças e adolescentes ainda permanece. Em 2008, as crianças ocupadas ainda representavam 0,9\% da população de 5 a 9 anos e 6,1\% da população entre 10 e 13 anos de idade (IBGE, 2009). Isso corresponde a um contingente de 4,5 milhões de crianças e adolescentes de 5 a 17 anos de idade no mercado de trabalho, estando 993 mil na faixa de 5 a 13 anos (idem, ibid.).

\section{Os números do trabalho infantil - PNAD (2008)}

Em 2008, 35,5\% das crianças e adolescentes de 5 a 17 anos de idade ocupadas exerciam uma atividade agrícola e 51,6\% eram empregados ou trabalhadores domésticos. Eles trabalhavam em média 26,8 horas habitualmente por semana, em todos os trabalhos, sendo que aqueles que tinham entre 5 e 13 anos de idade trabalhavam em média 16,1 horas; e aqueles com 14 ou 15 anos de idade, 24,2 horas; e os de 16 ou 17 anos de idade, 32,7 horas. Apenas 9,7\% dos empregados ou trabalhadores domésticos de 14 a 17 anos de idade possuíam carteira de trabalho assinada, percentual que era de $13,1 \%$ para aqueles com 16 ou 17 anos de idade. Das crianças e adolescentes de 5 a 17 anos de idade ocupados em $2008,32,2 \%$ eram trabalhadores não remunerados, percentual que chegava a $60,9 \%$ entre as crianças de 5 a 13 anos de idade. Daqueles que 
tinham 14 ou 15 anos de idade e estavam ocupados, 34,0\% eram trabalhadores não remunerados e, entre os adolescentes ocupados de 16 ou 17 anos de idade, esse percentual era de $19,1 \%$. O rendimento médio mensal de todos os trabalhos das crianças e adolescentes de 5 a 17 anos de idade ocupados aumentou de $\mathrm{R} \$ 262$, em 2007 , para $\mathrm{R} \$ 269$, em 2008. Aqueles com idade entre 5 e 13 anos recebiam em média $\mathrm{R} \$ 100$; os de 14 ou 15 anos de idade, R\$190; e os de 16 ou 17 anos, R\$ 319 . No Brasil, em 2008, 865 mil crianças e adolescentes de 5 a 17 anos de idade ocupadas residiam em domicílios cujo rendimento mensal domiciliar per capita era menor que $1 / 4$ do salário mínimo ou sem rendimentos, o que representa $10,8 \%$ do conjunto de pessoas nesse grupo de idade. O rendimento médio mensal domiciliar per capita das crianças de 5 a 9 anos de idade que estavam ocupadas era de $\mathrm{R} \$ 186$, ao passo que aquelas com 16 ou 17 anos de idade era de R\$394. (IBGE, 2009)

Tanto a rapidez com que essas transformaçôes tiveram lugar, quanto o fato de que elas parecem não ter chegado a todos os quadrantes do espaço social fazem com que o exame das relações que famílias dos grupos populares, principais implicadas, estabelecem com essa agenda política possa se constituir em objeto privilegiado para o estudo das modificações nas percepções sobre o valor social das crianças que tiveram lugar no Brasil contemporâneo.

\section{O que significa trabalhar?}

A transformação do trabalho infantil em problema social impulsionou, é verdade, uma multiplicidade de estudos que incidiu sobre diferentes aspectos do tema e contribuiu para ampliar de maneira substantiva a nossa compreensão sobre os fenômenos econômicos e sociais a ele associados. No entanto, como mostra Ferreira (2001), esses estudos ainda não ofereceram uma explicação convincente sobre a persistência do trabalho infantil em nossa sociedade. A explicação mais comumente apresentada tem como argumento central a pobreza das famílias. A necessidade material seria, nesse caso, o impulsionador do trabalho infantil.

No entanto, embora os casos de trabalho infantil sejam normalmente associados à extrema pobreza das famílias e da regiāo do país onde estas se encontram (Ferreira, 1999; Silva, 2000a), há estudos que mostram que a relação "pobreza-trabalho infantil" não se constitui de forma tão direta como elo causal. Um exemplo disso seria a inserção 
maciça de crianças e adolescentes no trabalho doméstico e na lavoura fumageira na região do Vale do Rio Pardo, no Rio Grande do Sul, um dos maiores polos produtores mundiais.

Como aponta Ferreira (1999), a pobreza talvez não componha o único elemento explicativo dessa inserção. Há que se considerar os fatores de natureza cultural e ideológica e também o fato de que as raízes econômicas são de outra ordem, notando-se entre elas a relação de subordinação que os pequenos produtores familiares estabelecem com os monopólios industriais transnacionais, definindo um vínculo que é, ao mesmo tempo, econômico e moral (Hoezel, 2000).

A cultura do fumo no Brasil, por exemplo, exige mão de obra intensiva num ciclo que dura cerca de dez meses, sendo norma o envolvimento de todo o grupo familiar. Assim, "a configuração de uma parcela significativa da força de trabalho infantil é devida a necessidades geradas no meio familiar" (Campos \& Alverga, 2001, p. 228), associada certamente às condições de vida, mas não condicionadas apenas por elas.

Isso mostra a pertinência de se avançar na interrogação sobre o lugar da criança no espaço econômico. Uma das maneiras de se fazer isso é tomar como objeto de estudo as percepçóes que envolvem as práticas relacionadas ao trabalho infantil por parte dos atores sociais mais diretamente envolvidos: as famílias dos grupos populares e suas crianças.

Como mostra Zelizer (1985), um dos problemas com que se debateram os proponentes e os opositores da legislação sobre o trabalho infantil nos Estados Unidos, no início do século XX, dizia respeito às questões de definição: Que ocupações específicas transformam uma criança em trabalhador explorado? O que determina a legitimidade de certas formas de trabalho? Uma garota que ajuda sua mãe nos cuidados com a casa pode ser considerada uma trabalhadora? Quando uma criança ajuda seus pais, ainda que esporadicamente, numa pequena loja ou feira, ela está trabalhando?

Trata-se aí de questôes que revelam a dificuldade enfrentada por órgãos internacionais e nacionais para definir as fronteiras entre o que é considerado trabalho infantil e o que é considerado uma prática aceitável (Azevedo, Menezes \& Fernandes, 2000; Neto, Neves \& Jayme, 2002). Para se compreender tais dificuldades, é importante enxergar as outras dimensões que cercam o trabalho infantil para além da econômica (Dauster, 1992). Trabalhar desde cedo, pelo menos para algumas 
famílias, pode ser percebido como uma regra moral, um princípio de socialização, baseado em um sistema de relações que se situa entre a cooperação e a troca.

Embora seja verdade que a legislação brasileira encontrou uma saída para essas inextrincáveis dificuldades de definição e estabelece, atualmente, com bastante clareza, as fronteiras entre "trabalho", "exploração" e "ajuda à mãe" etc., resta indagar se essa clareza encontra correspondente nas práticas e percepçōes das crianças e suas famílias.

Ao contrário de uma tendência notada na bibliografia (p. ex., Giovanni, 2002; Fonseca, 2003), esta pesquisa não partiu diretamente das crianças trabalhadoras encontradas num ambiente de trabalho determinado, mas foi buscá-las em suas moradias, junto às suas famílias.

Tomando como objeto de pesquisa as percepções das crianças e dos seus pais e mães sobre a questão, interessava problematizar não apenas aquelas situações em que a criança "está trabalhando", mas também aquelas em que a criança "já trabalhou" e algumas em que as famílias, embora partilhando a mesma situação econômica de outras, "resistem ou opõem-se a esse trabalho".

Com base nessa tipologia, foi localizado um conjunto de nove famílias moradoras de dois bairros populares vizinhos, localizados numa grande cidade do interior paulista. Foram realizadas entrevistas com mães $(n=9)$, pais $(n=7)$ e filhos que tinham entre 13 e 14 anos $(n=9) .^{3}$

Aos adultos foi solicitado um retorno sobre a história da família, suas memórias sobre as rotinas do dia a dia, as experiências escolares e de trabalho e os princípios educativos mais valorizados pelas famílias de origem e aqueles que eles próprios valorizavam na educação de seus filhos. As entrevistas foram realizadas em suas casas, o que permitiu uma observação mais detida das suas condiçōes de vida. ${ }^{4}$

Às crianças foi solicitada uma descrição pormenorizada de suas atividades cotidianas. Indagou-se sobre seus gostos e seus projetos de futuro, procurando-se estabelecer o lugar que aí atribuíam aos estudos e ao trabalho. As entrevistas com as crianças foram realizadas numa sala cedida pela escola pública municipal em que todos estudavam, numa tentativa de obter informações e impressões numa situação de maior independência com relação aos adultos da família. 


\section{As categorias de percep̧ça do trabalho}

Com relação aos resultados, foi possível perceber, primeiro, que a noção de "trabalho" não remete a um universo absolutamente homogêneo de práticas, mas se define fundamentalmente por oposição a uma categoria muito frequente nas entrevistas: a "ajuda".

O significado prático, concreto, de cada uma das categorias acompanha clivagens geracionais que são, ao mesmo tempo, familiares e sociais. Esse é um efeito direto dos dois princípios operatórios na constituição da população que compõe o estudo - a idade das crianças e o bairro de moradia -, que agregou famílias muito próximas no espaço social, em vários sentidos (idade, ocupação, escolarização, passado rural e experiência de migração numa conjuntura história particular). ${ }^{5}$

A noção de geração serve, assim, como princípio de inteligibilidade das percepçôes esboçadas pelo grupo de pais e pelo grupo dos filhos, com relação ao trabalho das crianças, tal como será demonstrado mais adiante. No entanto, é importante notar desde já que, para além das experiências compartilhadas, há diferenças nas histórias familiares suficientemente significativas para provocarem nuances entre as posiçôes assumidas por indivíduos de uma mesma geração. ${ }^{6}$

Para a geração mais nova, encontramos uma tendência a se pensar em "trabalho" quando se refere a um serviço remunerado, realizado fora do espaço das relações de ajuda mútua estabelecido no interior do grupo de parentesco. Assim, ajudar a tia que vende roupas, num momento de aperto, em troca de algumas blusas e calçôes, não é visto como "trabalho", mas como "ajuda". Da mesma maneira, arrumar a casa e cozinhar o feijāo para a mãe encontrá-lo pronto, quando for fazer o jantar à noite, entre outras práticas do tipo, não são considerados trabalho, mas, sim, ajuda, mesmo quando isso envolve alguma retribuição financeira.

Diferentemente, varrer a chácara para outra família, regularmente ou ocasionalmente, serviço obtido por meio de redes de amigos dos pais, com o objetivo expresso de juntar um "dinheirinho" para o lanche ou pequenos gastos, é considerado trabalho para a geração mais nova, que também considera como trabalho a ajuda dada ao pai, pedreiro, na obra, aos sábados, em troca de remuneração. 
$\mathrm{O}$ que parece diferenciar essa situação do caso da ajuda à tia ou do trabalho ocasionalmente remunerado em sua própria casa - duas situações mencionadas anteriormente - é o sentido atribuído a uma e a outra. Enquanto a ajuda parece ser vista como uma resposta improvisada a um pedido de socorro, o trabalho com o pai é entendido como entrada numa situação de aprendizagem e experimentação do ofício. Componente dos processos mais amplos da "educação de crianças", essa experiência deveria ser vivida em todas as suas dimensões, inclusive no que diz respeito ao cumprimento dos horários, à postura com relação aos co-trabalhadores e, por último, mas não menos importante, ao direito de receber uma remuneração compatível.

Para a geração mais velha, tanto a categoria trabalho como a categoria ajuda se referem a um universo de práticas que remetem ao uso mais intenso do corpo e do tempo e a uma relação de pouca autonomia para com a remuneração. Ajudar significa limpar a casa, cuidar dos irmãos mais novos, cozinhar, lavar a roupa.

"Desde criança [eu ajudo]. Eu tinha o que... uns cinco anos. Na época a gente morava (...) em Bauru. A gente morava na fazenda do primo do meu pai, minha mãe trabalhava no café e eu ficava em casa (...). Eu varria, eu passava pano, pegava aquela bacia, baciona de louça, lá fora e lavava tudo, porque naquele tempo não tinha pia, naquele tempo era jirau, né? Botava em cima do jirau e lavava toda a louça, limpava o fogão de lenha, ficava tudo arrumadinho. Aí quando a mãe chegava estava tudo arrumadinho, tudo limpinho". (Marlene, 41 anos, empregada doméstica)

Para essa geração, a ajuda refere-se também à participação de meninos e meninas nas atividades remuneradas dos adultos, como, por exemplo, nas encomendas da mãe costureira, como uma estratégia para aumentar o rendimento do seu trabalho, ou no cuidado de animais, no sítio, para aliviar um pouco o trabalho do pai.

"Quando eu era criança, minha mãe já era costureira então... eu só via, eu ficava muito... Ela costurava assim à noite até... e eu ficava fazendo as minhas liçóes e do lado dela, ela costurando e às vezes eu ajudava, ela ainda não tinha máquinas... como hoje, a gente tem máquinas melhores... tinha muito serviços de mão. Então eu ajudava ela fazer e quando eu tinha 12 anos aí... eu fui numa senhora que me ensinou a fazer... tirar medidas e molde. Que aí eu já sabia... a costura reta eu já sabia, então naquele tempo eu comecei a costurar...”. (Graça, 47 anos, costureira) 
"O meu pai era retireiro, né, então como ele era sozinho... Ele levantava [às] três horas da madrugada pra poder ir para a cocheira tirar leite, que é tirado tudo na mão. Então... pra ficar abrindo porteira, pra soltar as vacas, aí ele chamava nós, de madrugada, pra poder ajudar ele”. (Edson, 38 anos, pedreiro)

Em nenhum dos casos, jamais se considerava que essa ajuda desse direito à participação na remuneração, percebida como algo que pertencia exclusivamente ao universo dos adultos.

"A gente ia com a mãe e colhia algodão. Ficava tudo para ela, para poder ajudar em casa (...). Doem demais as costas da gente, meu Deus, aquele peso o dia inteirinho, aquele sol ardendo no ombro, as costas formigavam e você tá ali, tem que colher, tem que colher, porque é por arroba. Então você tem que render. [risos]. Tem que render para poder chegar no final do dia e recolher o dinheiro que você ganhou. Era o dia inteiro. A gente começava sete horas e ia até umas cinco, cinco e meia. O caminhão passava cinco horas da manhã e pegava a gente e levava a gente até o lugar e, depois, cinco horas, pegava a gente de volta”. (Marlene, 41 anos, empregada doméstica)

Para a geração mais nova, a ajuda continua presente e as diferenças entre meninos e meninas parecem estar associadas à intensidade do esforço. Para os meninos, quando referida ao serviço doméstico - varrer a casa e o quintal, lavar louças -, ela é mais esporádica e ocasional:

(E você sabe cozinhar?) Não muito bem. (Evocê [cozinha]?) Ah, quando a minha mãe... tipo, chega cansada, sabe, tá cansada, eu faço [comida]. (André, 13 anos)

\section{E pode se tornar objeto de negociação:}

[Não gosto de] ficar lavando prato. Pelo amor de Deus... Minha mãe pede para eu recolher a roupa e eu vou. Ou varrer a casa. Se a minha mãe está ocupada, lavando roupa, ela me manda lavar os pratos. Aí eu falo que não dá, [falo] que eu estou ocupado. [E aí você não vai ou você vai?] Ah, aí eu falo pra ela... se ela vai me dar algum dinheiro para eu comprar lanche à noite. Aí, se ela fala que dá, aí eu vou lavar. (André, 13 anos)

Para as meninas, a ajuda doméstica é tratada mais no registro da "obrigação", isto é, são atividades cotidianas regulares que podem ser bastante intensas, vivenciadas a partir de um enquadramento moral mais explícito e uma maior consciência do valor econômico delas derivado: 
"Lá em casa, sou eu quem cuida das coisas. Então eu tenho que acordar e já ir arrumando, ajudando a minha mãe. (...) Eu acordo, como alguma coisa, mais rápido, e assisto um pouco de televisão e daí eu arrumo alguma coisa lá em casa, faço almoço (...), limpo a cozinha. Cozinho para mim, para o meu pai e para minha mãe. Eles almoçam lá também. $\mathrm{Na}$ janta (tem) minha irmã. [Quantos anos você tinha quando começou a cozinhar?] Ah, cozinhar não faz muito tempo, porque que minha mãe não gosta que eu fique mexendo com fogo. (...) Acho que uns onze, dez. [E o que você acha disso?] Ah, eu acho legal, porque... assim, eu não acho chato cozinhar, eu gosto. [Tem alguma coisa que você não gosta de fazer na sua casa?] Ah, eu não gosto de lavar louça (...). Eu odeio lavar louça! [ $E$ você tem que lavar louça?] Tenho, porque se eu não lavar de manhã eu tenho que lavar de tarde ou, se não, eu vou deixar pra minha irmã. E a minha irmã chega à meia-noite. Então eu acho... se eu fico a manhã inteira em casa, eu ajudo (...). Se eu não ajudar, [a minha mãe] vai ter que fazer. O que eu não faço, ela vai ter que fazer, vai perder tempo de costurar, vai perder tempo de ganhar dinheiro. Então, acho melhor eu ajudar ela, e ficar todo mundo bem". (Stéfani, 13 anos)

Com relação à categoria trabalho, por sua vez, a mudança é mais profunda. Para as mulheres da primeira geração, trabalho refere-se à entrada, quando meninas, na ocupação de babás entre os 7 e os 8 anos de idade, em troca de roupas e/ou alimentos.

"Na época, meus pais eram muito pobres. (...) e não podiam comprar nem roupa nem calçado para mim. E eu estava na escola. Aí, já viu, né? Quer andar na escola toda bonitinha, né? Eu só tinha um chinelo Havaianas para ir para escola. Então eu queria ir de sapatinho, queria um vestidinho bonitinho, né? Então eu comecei a trabalhar com oito anos, cuidava de duas crianças e em troca a mulher me dava um par de sapatos, às vezes comprava um vestidinho". (Marlene, 41 anos, empregada doméstica)

Para os homens desta primeira geração, trabalho refere-se a entrar, também entre 7 e 8 anos, em ocupações como ajudante de pedreiro, mecânico, entre outras. A decisão de trabalhar aparece nas falas de uns e outros como tendo partido deles próprios ou dos adultos, embora sempre como uma reação a constrangimentos que aparecem naturalizados e a um enquadramento moral perceptível.

"[Eu trabalho] Desde os doze anos. [Aos] doze anos eu entrei na oficina. [E como foi essa sua entrada na oficina?] Fui eu quem foi atrás. Fui a várias, até [chegar] nessa oficina [mecânica] onde eu trabalhei. Eu entrei 
com doze anos e saí com vinte e dois de lá. [E por que você foi procurar emprego?]Ah... é... eu acho que... eu acho que... foi porque a família inteira começou cedo. Então eu acho que a gente vai pegando aquele ritmo da família, tudo começou cedo. Por que eu não?”. (Vanderlei, 41 anos, mecânico de automóveis)

Para a geração mais nova, por sua vez, trabalho refere-se a "bicos”, pelo menos antes de chegarem à idade em que estarão autorizados a assumir um contrato legal. Eles procuram por ocupações em que não se cansem muito e esperam uma remuneração financeira que é, invariavelmente, muito baixa.

A opção pelo trabalho é percebida como uma questão de foro íntimo, movida pelo desejo de ganhar certa independência, o que significa, pelo menos em parte, acesso a certos itens de consumo, como lanches e roupas "de marca". Ela está pouco relacionada, pelo menos no discurso dos nossos pequenos entrevistados, às exigências dos pais ou a alguma ajuda que pensam dever à família nesse momento de suas vidas.

Isso parece explicar o fato de que guardam para si a pequena remuneração recebida, ao contrário do que acontecia com seus pais. Ao mesmo tempo, isso indica o quanto mudou a posição das crianças no seio das famílias (Linhares, 2004, 2008), autorizadas hoje a se perceberem como pequenos consumidores, sujeitos de desejos e expectativas, em suma, mais autônomos do que foi permitido a seus pais e mães quando tinham a mesma idade.

"[Já trabalhei como] Vendedor de flores. (...) Vendia no CEAGESP de São Paulo. [Você trabalhava de que horas a que horas?] Eu ia... de noite... aí ficava da noite até o meio dia, até uma hora da tarde. [Você se lembra do horário em que entrava no serviço?] Entrava uma hora da manhã, eu entrava junto com o meu pai e ele ia para boxe em que ele trabalhava e eu ia pro meu. [E você era registrado?] Não. [Você recebia?] Recebia. Cheguei a tirar uns troco para poder pagar o almoço, mas eu trabalhava porque eu gostava de lá. [E o que você fazia com o dinheiro que você recebia?] Comprava o almoço meu e do meu pai ou então comprava só o meu. [Não dava pra fazer mais além disso?] Dava, só que eu gostava, gastava mais é com comida, essas coisas. Gostava muito de comer, né? Então gastava muito mais é com comida. Comida, lanche. [Quanto você recebia?] Por semana, recebia cinquenta [Com quantos anos você começou a trabalhar lá?] Eu comecei com onze”. (João Pedro, 14 anos, trabalhava durante as férias) 
Como se vê, então, "trabalho" e "ajuda" remetem a universos de práticas bastante distintos. No entanto, não é possível compreender inteiramente o sentido atribuído a um e outro sem levar em conta que ambos opõem-se de imediato, e principalmente, a um terceiro: a escola.

\section{Escola primeiro, trabalho depois}

Quando as entrevistas foram realizadas, as crianças estavam na $7^{\text {a }}$ série do ensino fundamental. Elas fizeram questão de deixar muito clara a prioridade que atribuíam à escola sobre o trabalho e sobre a ajuda:

"Às vezes ajudo meu pai, de mecânico. [E o que você faz?] Eu trabalho com ele. Vou assim... lavar peças... arrumar buggie. Lá tem gente que é rico e daí tem uns buggies da molecada e tem umas coisas que eu arrumo. [E você gosta?] [Balança a cabeça positivamente.] Ah, eu acho legal trabalhar com ele. Aprendi a dirigir os buggies. [E quando você vai nesse trabalho do seu pai?] Ah, só dia de sábado, quando não tem aula. E se não tem nada para fazer. [E você recebe por esse trabalho?] Recebo. (...) Vinte e cinco [por dia]". (Luciano, 14 anos)

"Às vezes, tem dia da semana que eu venho mais cedo aqui para a escola. [Fico] o dia inteiro. [Ảs vezes] é a semana inteira e [às vezes] volto mais tarde a semana inteira, porque a semana é muito corrida. Aí não dá [para ajudar]. Mas sempre quando eu tenho tempo eu tento ajudar". (Stéfani, 13 anos)

No que concordam seus pais:

"Quando tá na hora dela ir pra aula, se tiver uma coisa assim pra fazer eu nunca deixo [ficar]. Assim, primeiro a responsabilidade dela é o estudo, primeiro. É a única coisa que ela tem que [fazer] nem que para isso eu precise pegar no pé. Ela é muito estudiosa. Se tem que fazer alguma coisa ela já fala: 'hoje eu tenho... amanhã eu tenho prova, ou tenho tal trabalho, ou tenho isso pra fazer'. Então, eu não [tenho] que... a responsabilidade dela por enquanto é a escola”. (Graça, 47 anos, costureira)

“[Ele] ajuda às vezes por vontade própria. Às vezes eu peço pra fazer alguma coisa, se não tiver lição de escola, né? Se não tiver nada pra fazer, aí ele faz. Que nem agora, põe a máquina pra bater roupa, lava uma louça, faz alguma coisa, mas eu sempre dou espaço pra tá fazendo a lição de casa". (Silvana, 38 anos, faxineira) 
Essa posição privilegiada da escola está muito relacionada à "falta" dos estudos que todos os pais dizem sentir, lamentando não terem tido condições, na infância e adolescência, de prosseguir com os estudos.

"Acho que faz muita falta, faz muita falta mesmo, gente. Meus estudo faz muita falta pra mim. [E você gostava de estudar naquela época?] Num era que não gostava não, né? Era que o lugar não tinha escola. E não tinha o recurso também que hoje tem a escola. Que os livros... a gente tinha que comprar, na época, os livros. Aí nós era pequeno, minha mãe catava ferro velho para conseguir dinheiro prá comprar os livro, porque livro tava escondido, tinha que comprar ele, né? (...). E lá num tinha [escola perto], era um latifúndio... embaixo de sol. E hoje, se vai à escola, dá tudo, dá alimentação, né? E [antes] tinha que ficar todo dia no sol e agora fica o dia todo na escola. Completamente diferente". (Vera, 41 anos, desempregada)

"Eu acredito que antigamente... o governo, não tinha, não dava essa oportunidade que dá pras crianças de hoje. Era tudo mais difícil. Então começou dar aqueles negócio, aula de inglês e livro, e um dia a professora falou assim pra mim: se amanhã você não trouxer o livro de inglês você não vai participar da aula. Aí eu fiquei muito aborrecido com ela e não falei nada e saí [para] procurar emprego, consegui e não voltei mais pra escola. E foi bem por aî". (Vanderlei, 41 anos, mecânico de automóveis)

E atribuindo muitas das suas dificuldades, embora não todas, a essa falta, alguns pais procuraram e ainda procuram, depois de adultos, fazer o supletivo. Outros dizem ter o sonho de voltar a estudar, mas avaliam não ter condiçôes de conciliar a dura jornada de trabalho com os cursos noturnos. E todos dizem não poupar sacrifícios para garantir que seus filhos tenham a escola "como única obrigação".

Suas estratégias se complicam quando percebem quão pouco o sistema de ensino tem a oferecer a suas crianças, apesar de todas as transformações por que passou a escola brasileira e de que são testemunhas. Esse é o terceiro elemento que, interagindo com a posição social, orienta as ambiguidades dos mais velhos com relação à oposição escola/trabalho.

Assim, embora apostando na escola como instrumento de construção de um futuro melhor para seus filhos, esses pais e mães são confrontados cotidianamente com o fato de que poucos, entre crianças e jovens com quem convivem, conseguem de fato garantir uma trajetória de longa duração na escola. 
Não é surpresa, portanto, que a valorização da inserção precoce no mercado de trabalho esteja mais presente entre aquelas famílias de pior posição social, que têm filhos mais velhos do que os jovens entrevistados para esta pesquisa e que, portanto, têm uma experiência de primeira mão com a dificuldade de se construir um futuro pela escola.

\section{Histórias de família, histórias de trabalho e entrada no mercado de trabalho}

Ocorre, portanto, uma relação muito forte e estreita entre as formas de se definir o lugar do trabalho das crianças nas estratégias educativas e as experiências de trabalho dos pais e mães, quando eles próprios eram crianças.

De uma geração a outra, as famílias permanecem confrontadas com a mesma contradição: a disposição para incentivar os filhos e filhas a investir na escola é contraposta tanto à pouca esperança de ver esse investimento dar frutos, quanto ao medo de que o adiamento da entrada no mercado de trabalho tenha um efeito nocivo sobre a estrutura moral dos seus filhos. O trabalho assume, então, uma dupla função: proteger contra um mau investimento e preparar para o futuro.

"Não se lida com filho hoje. Se tiver alguma coisa passando pela cabeça
deles... eu acho que fica aquela coisa na cabeça e acaba que essas coisa...
[O trabalho ajudaria a] não ficar perdendo tempo pra rua. Trabalho sem-
pre ocupa a cabeça. Porque a gente foi, nasceu tudo numa família pobre,
né? Porque nós éramos tão pequenos e não ouvia falar nisso. Naquela
época não tinha isso que tem hoje. Nem droga, né? Acho que se ocupar
cedo a cabeça deles, não vai para esses caminhos". (Vera, 41 anos, desem-
pregada) A ajuda é objeto de uma elaboração parecida:

"Precisa [ajudar em casa] porque se é da máquina que eu tiro o dinheiro pra dar pra ela, então, como que ela vai ficar (...) sentada e eu costurando e eu [vou ter que] correr, fazer a comida, pôr na mão dela, fazer tudo e pôr na mão dela. Então, não é justo, não é sempre que ela vai me ter (...). Como eu vou deixar ela despreparada? (...). Eu acho que, independente de ter condição financeira boa ou não, eu acho que a pessoa precisa, sim, aprender a fazer alguma coisa e saber. Eu acho que se ela tá vivendo aqui, não é certo ela ficar sem fazer nada e ficar 
no meio da bagunça porque eu não posso fazer, porque eu não tenho tempo. Então, ela ajuda sim”. (Graça, 47 anos, costureira)

Embora, de uma maneira geral, todas as famílias depositem grandes esperanças na escola para a construção de um futuro interessante para as crianças e a maioria tenha expressado o desejo de que os filhos venham a fazer "uma faculdade", há diferenças significativas entre elas que não estão distribuídas aleatoriamente entre os pais focalizados, mas acompanham as diferenças nas histórias de suas famílias, de que são tributárias as atuais diferenças de posição social.

A maneira como os adultos chegaram ao mercado de trabalho define, em grande medida, o lugar que estes atribuem ao trabalho na educação de seus filhos. Aqueles pais e mães que começaram a trabalhar mais cedo e em condiçôes mais penosas tendem a liberar os filhos para a escola com maior frequência do que aqueles pais que começaram a trabalhar mais tarde e em condições menos duras. ${ }^{7}$

Para os primeiros, o trabalho remunerado era visto como algo que deveria ser iniciado após os 16 anos de idade ou após a finalização dos estudos, já que o trabalho na infância "sacrifica" e não dá "um bom futuro", justificando-se isso sempre com a própria história de vida. Para os últimos, o trabalho "educa" e não deve ser adiado, embora a lei os obrigue a adiar "um pouco mais do que o necessário".

A própria história de escolarização também se articula com posiçóes diferentes sobre o trabalho. Há casos de pais que gostariam que seus filhos só começassem a trabalhar após concluir um curso superior e há outros casos em que os pais acreditam que os filhos deveriam estudar e trabalhar ao mesmo tempo, com o objetivo de irem se "acostumando" com a vida laboriosa, para que, quando adultos, encontrem "ânimo" para trabalhar.

Em geral, a história nas ocupações e a história de escolarização se misturam para definir essas posições. Assim, para Sivaldo (35 anos, pedreiro, $4^{a}$ série supletivo), por exemplo, se a criança não conseguir conciliar o estudo com o trabalho, é preferível que comece a trabalhar mais tarde do que parar de estudar mais cedo. Porém, para ele, o "bom de começar a trabalhar cedo" é que a pessoa "começa a se virar" e a se "valorizar", já que quem demora muito para conseguir um emprego, quando for trabalhar, não terá muita "disponibilidade" e gosto pelo trabalho. 
Já Nailton (36 anos), por outro lado, que conseguiu chegar mais longe na escola (à $1^{\text {a }}$ série do ensino médio supletivo) e tem uma ocupação um tanto mais leve (trabalha como entregador para uma cooperativa produtora de hortifrutigranjeiros), diz acreditar que seu filho deve começar a trabalhar somente após a conclusão de uma "faculdade", para não correr o risco de "ficar pelo caminho".

A apreciação positiva da experiência do trabalho precoce a que foram submetidos é generalizada entre a geração mais velha. Os pais e mães atribuem ao fato de terem trabalhado "desde cedo" o aprendizado de competências e habilidades e, particularmente, a construção de uma capacidade para "se virar". No entanto, para eles, essa capacidade só é importante e sua aquisição só deve ser estimulada porque o futuro aberto pela escola parece incerto, imprevisível e incontrolável.

"[O que você espera para of futuro do seu filho?] Ah, eu espero que seja um homem de bem, um homem pra arrumar uma profissão boa. Um homem responsável. E que não pare com os estudos que nem eu parei (...). Que continue, pra ser alguém na vida. Eu não consegui ser, então, eu peço pra Deus que ele consiga". (Vanderlei, 41 anos, mecânico de automóveis)

\section{Considerações finais}

A permanência do trabalho infantil entre famílias dos grupos populares, a despeito da forte militância que se organizou contra ele e a despeito também da expansão dos programas sociais que têm como objetivo apoiar e fortalecer os investimentos escolares das famílias, pede por estudos que se disponham a compreender o significado atribuído ao trabalho das crianças por esses grupos sociais.

Os nossos resultados indicam a produtividade de uma abordagem geracional que problematize as transformações nas condições de existência das famílias ao longo do tempo e as tenha como princípio explicativo das tomadas de posição no presente sobre os investimentos no futuro dos filhos.

As famílias em foco nesta pesquisa percebem, com bastante clareza, que a entrada no mercado de trabalho implica relegar a segundo plano o investimento na escola. Não obstante, a valorização do lugar desempenhado pelo trabalho nas suas vidas, principalmente como dispositivo 
de enquadramento moral, faz com que elas, na ausência de uma confiança no futuro construído pela escola, aceitem e mesmo estimulem seus filhos a considerar a entrada no mercado de trabalho desde muito cedo.

Essas conclusões têm implicações concretas para o debate em torno das políticas para erradicação do trabalho infantil, na medida em que reforçam o argumento de que o afastamento das crianças dos grupos populares do trabalho precoce parece estar condicionado, para além das situaçôes de extrema pobreza, pela possibilidade das famílias e crianças acreditarem que é possível construir um futuro pela escola.

\section{Recebido em maio de 2010 e aprovado em junho de 2010.}

\section{Notas}

1. Ver Bourdieu (1998a e b, 2002, 2006) e Baudelot e Establet (2000) para um enquadramento mais preciso das questōes téoricas e empíricas associadas ao estudo dos processos de transmissão, particularmente quando são tomados para se compreender a entrada ou permanência em ocupações do mercado de trabalho.

2. A literatura especializada produzida em torno do tema do trabalho infantil pode ser classificada em dois grupos: o primeiro reúne estudos cujo objetivo e escopo são fundamentalmente atestar os prejuízos do trabalho infantil para os mercados, as sociedades, as famílias e os jovens trabalhadores. Esse é o caso da maioria dos trabalhos produzidos por economistas ou por inspiração da teoria econômica (ver, por exemplo, Basu \& Van, 1998; Basu, 1999; Psacharopoulos, 1997; Edmonds \& Pavcnik, 2005; Schwartzman \& Schwartzman, 2004). Na medida em que a erradicação do trabalho infantil é um ponto importante da agenda de várias agências multilaterais, pelo menos desde os anos de 1940, essa concentração temática não chega a surpreender. O segundo grupo, cujos achados discutiremos a seguir, reúne estudos cujos objetivos voltam-se mais para a tentativa de compreender os processos políticos e culturais que culminaram na definição do trabalho infantil como algo indesejável, tanto em termos legais quanto em termos das sensibilidades.

3. Talvez seja importante chamar a atenção para o fato de que as crianças mais jovens ainda não tinham idade que lhes permitisse trabalhar legalmente. As mais velhas do grupo, por sua vez, haviam acabado de completar 14 anos e encontravam-se na $7^{\text {a }}$ série. Não havia, por parte de nenhuma delas nem de suas famílias, o projeto imediato de inserção em programas de trabalho da categoria "aprendiz", o que é permitido por lei. Ver, sobre esse tipo de inserção, Fonseca (2003).

4. A produção de "histórias de família" é um recurso eficaz para se captar com maior precisão a posição social dos indivíduos em foco, na medida em que permite identificar não apenas o volume e estrutura do patrimônio material e simbólico detido pelo grupo familiar num momento dado, como também as condiçôes de aquisição desse patrimônio. Com isso, colocamos em andamento uma análise que reserva à posição de classe um lugar privilegiado na explicação das tomadas de posição sobre o tema em discussão. Para uma discussão mais abrangente dessa posição, que é, ao mesmo tempo, teórica e metodológica, remetemos o leitor às obras de Pierre Bourdieu, particularmente $A$ distinção (2006) e $A$ miséria do mundo (1998b).

Educ. Soc., Campinas, v. 31, n. 111, p. 347-369, abr.-jun. 2010

Disponível em <http://www.cedes.unicamp.br> 
Permanências e mutações na definição intergeracional do trabalho infantil

5. Trata-se aqui de homens e mulheres com idades variando entre 33 e 56 anos (com uma maior concentração entre 38 e 41 anos), em ocupaçôes manuais (empregadas domésticas, costureiras, pedreiros, mecânicos de automóveis), em geral com baixa escolarização, embora um dos pais e uma das mães tenham chegado ao $1^{\circ}$ ano do ensino médio por meio do curso supletivo. Todos, sem exceção, passaram a infância no campo, como filhos de lavradores, em diferentes regiōes do Brasil (interior do Ceará e da Bahia, Goiás, norte e sul de Minas Gerais, interior de São Paulo), todas igualmente desprovidas de serviços educacionais e oportunidades de emprego para os mais jovens, e experimentaram a migração para Campinas em diferentes momentos de suas vidas. Nessa homogeneidade de experiências reside a possibilidade de serem tratadas como "geração".

6. Para uma discussão conceitual das questôes envolvidas nessa abordagem geracional, remetemos o leitor ao artigo de Kimi Tomizaki publicado neste mesmo número.

7. Nós procuramos, assim, por indícios que nos permitissem associar a percepção sobre o futuro possível à posição de classe. Ver, sobre isso, Bourdieu (1998).

\section{Referências}

ARIÈS, P. História social da criança e da família. Rio de Janeiro: Zahar, 1981.

AZEVEDO, J.S.G.; MENEZES, W.F.; FERNANDES, C.M. Fora de lugar: crianças e adolescentes no mercado de trabalho. São Paulo: ABET, 2000. (Teses \& Pesquisas, v. 2).

BASU, K.; VAN, P.H. The economics of child labor. The American Economic Review, Pittsburgh, v. 88, n. 3, p. 412-427, June 1998.

BASU, K. Child labor: cause, consequence, and cure, with remarks on international labor standards. Journal of Economic Literature, Pittsburgh, v. 37, n. 3, p. 1083-1119, Sept. 1999.

BAUDELOT, C.; ESTABLET, E. Avoir 30 ans en 1968 et en 1998. Paris: Seuil, 2000.

BOURDIEU, P. Futuro de classe e causalidade do provável. In: Nogueira, M.A.; Catani, A. (Org.). Pierre Bourdieu: escritos de educação. Petrópolis: Vozes, 1998a. p. 81-126.

BOURDIEU, P. As contradiçōes da herança. In: Bourdieu, P. A miséria do mundo. Petrópolis: Vozes, 1998b. p. 229-237.

BOURDIEU, P. Le bal des célibataires: crise de la société paysanne em Béarn. Paris: Seuil, 2002. 
BOURDiEU, P. Classes e classificações. In: Bourdieu, P. A distinção: crítica social do julgamento. São Paulo: Edusp; Porto Alegre: Zouk, 2006. p. 434-447.

BRASIL. Plano nacional de prevenção e erradicação do trabalho infantil e proteção ao trabalhador adolescente. Brasília, DF: Ministério do Trabalho e Emprego; Secretaria de Inspeção do Trabalho, 2004.

CAMPOS, H.R.; ALVERGA, A. Trabalho infantil e ideologia: contribuição ao estudo da crença indiscriminada na dignidade do trabalho. Estudos Psicológicos, Natal, v. 6, n. 2, p. 227-233, 2001.

DAUSTER, T. Uma infância de curta duração: trabalho e escola. Cadernos de Pesquisa, São Paulo, n. 82, p. 31-36, 1992.

EDMONDS, E.V.; PAVCNIK, N. Child labor in the global economy. The Journal of Economic Perspectives, Nashville, v. 19, n. 1, p. 199-220, 2005.

FERREIRA, M.A.F. Investigação dos comprometimentos do trabalho precoce na saúde de crianças e adolescentes. Brasília, DF: MTB/OIT, 1999. (Relatório de pesquisa).

FERREIRA, M.A.F. Trabalho infantil e produção acadêmica nos anos 90: tópicos para reflexão. Estudos de Psicologia, Natal, v. 6, n. 2, p. 213-225, 2001.

FERREIRA, M.A.F.; VALENZUELA, M.C. Estudo epidemiológico dos acidentes de trabalho em Porto Alegre. Porto Alegre: Escola de Saúde Pública, 1998.

FERRO, A.R.; KASSOUF, A.L. Avaliação do impacto dos programas de bolsa escola sobre o trabalho infantil no Brasil. Pesquisa \& Planejamento Econômico, Rio de Janeiro, v. 35, n. 3, p. 417-444, 2005.

FONSECA, J.C. Adolescência e trabalho. São Paulo: Summus, 2003.

GIOVANNI, G. Trabalho infantil em Campinas. Campinas: UNICAMP; IE; NEPP, 2002.

HOELZEL, F. O trabalho precoce e projetos de vida: um estudo em crianças e adolescentes do meio rural de Santa Cruz do Sul. 2000. Dissertação (Mestrado em Desenvolvimento Regional) - Universidade de Santa Cruz do Sul, Santa Cruz do Sul. 
INSTITUTO BRASILEIRO DE GEOGRAFIA E ESTATISTICA (IBGE). Pesquisa Nacional por Amostra de Domicílios: 2008. Brasília, DF: IBGE, 2009. Disponível em: <http://www.ibge.gov.br/ home/presidencia/noticias/noticia_visualiza.php?id_noticia=1455\&id_pagina=1>. Acesso em: 23 mar. 2010.

LENOIR, R. Objeto sociológico e problema social. In: Champagne, P. Iniciação à prática sociológica. Petrópolis: Vozes, 1998.

LINHARES, E.F. Entre escravos e anjos: condições e significados da infância em um assentamento rural fluminense. 2004. Tese (Doutorado) - Instituto de Filosofia e Ciências Sociais, Universidade Federal do Rio de Janeiro, Rio de Janeiro.

LINHARES, E.F. Escravos na roça, anjos na escola. Tempo Social, São Paulo, v. 20, n. 1, p. 95-117, 2008.

MARQUES, V.R.B. Histórias de higienização pelo trabalho: crianças paranaenses nos novecentos. Cadernos CEDES, Campinas, v. 23, n. 59, p. 57-78, abr. 2003.

MARTINS, J.S. Massacre dos inocentes: a criança sem infância no Brasil. 2. ed. São Paulo: HUCiTec, 1993.

MEDEIROS, M. A importância de se conhecer melhor as famílias para a elaboração de políticas sociais na América Latina. Planejamento \& Políticas Públicas, Rio de Janeiro, n. 22, p. 48-71, dez. 2000.

NETO, A.C.; NEVES, M.A.; JAYME, J.G. Setor informal: abrigo para o trabalho infantil. In: Marques, M.E.; Neves, M.A.; Neto, A.C. (Org.). Trabalho infantil: a infância roubada. Belo Horizonte: PUC-MG; Instituto de Relações do Trabalho, 2002. p. 79-98.

NOGUEIRA C.S.R.S. Trabalho infantil e familias em regioes metropolitanas brasileiras. 2003. Dissertação (Mestrado em Economia Social e Trabalho) - Instituto de Economia, Universidade Estadual de Campinas, Campinas.

OLIVEIRA, D.C. et al. Futuro e liberdade: o trabalho e a instituição escolar nas representaçóes sociais de adolescentes. Estudos de Psicologia, Natal, v. 6, n. 2, p. 245-258, 2001. 
PIRES, J.M. Trabalho infantil: a necessidade e a persistência. 1988. 310f. Dissertação (Mestrado em Economia) - Faculdade de Economia e Administração, Universidade de São Paulo, São Paulo.

PSACHAROPOULOS, G. Child labor versus educational attainment some evidence from Latin America. Journal of Population Economics, Berlin, v. 10, n. 4, p. 377-386, Oct. 1997.

SCHWARTZMAN, S.; SCHWARTZMAN, F. Tendências do trabalho infantil no Brasil entre 1992 e 2002. Brasília, DF: OIT, 2004. Disponível em: <http://www.schwartzman.org.br/simon/pdf/trab_inf2004.pdf> Acesso em: 14 fev. 2010.

SILVA, R.B.F. Trabalho infantil e construção da identidade de gênero. 2000a. Dissertação (Mestrado em Desenvolvimento Regional) - Universidade de Santa Cruz do Sul, Santa Cruz do Sul.

SILVA, M.R. $O$ assalto à infância no mundo amargo da cana-de-açúcar: onde está o lazer lúdico? O gato comeu? 2000b. Tese (Doutorado em Ciências Sociais Aplicadas à Educação) - Faculdade de Educação, Universidade Estadual de Campinas, Campinas.

ZELIZER, V. Pricing the priceless child: the changing social value of children. New York: Basic Books, 1985. 
